2. Haase N.U. Veränderungen der Inhaltsstoffe von Speisekartoffeen durch Lagerung und Verarbeitung / N.U. Haase // Kartoffelbau. - 2002. - v.53. - № 7. - p. 284-289.

3. Шпаар Д. Картофель (выращивание, уборка, хранение) / Д. Шпаар // М.: ООО «ДЛВ Агродело», 2007. - 457 с.

DOI 10.18699/GPB2020-109

\title{
Влияние марганца на всхожесть и линейный рост корневой системы ячменя разных сортов
}

Симонова O.A. ${ }^{\text {* }}$, к.с.-х.н., н.с.; Симонов M.B. ${ }^{2}$, к.т.н., доцент; Товстик Е.В. ${ }^{2}$, к.б.н, доиент.

${ }^{l}$ ФБНУ ФАНЦ Северо-Востока, г. Киров, Россия;

${ }^{2}$ ФГБОУ ВО Вятский государственный университет, г. Киров, Россия. *e-mail: simolga07@gmail.com

В статье приведень результаты исследования влияния ионов марганйа (II) в коничентрациях 30,0; 60,0 и 90,0 мг/л на растения ячменя. Растения вырашчвали в водной культуре в течение 7-ми суток. Оценивали 6 сортов ячменя, в том числе 5 из коллекции лаборатории селекции и первичного семеноводства ячменя ФГБНУ ФАНЦ Северо-Востока. Установлено, что исследованные дозы марганца не оказали значимого влияния на прорастание семян. В тоже время с увеличением концентрации марганца в среде для вырашивания растений ячменя прочзошло закономерное уменьшение длины корней. Районированные сорта ячменя, по сравнению со стандартныл сортом Белгородский 100, по параметру длина корней и значениям индекса длины корней (ИДК) оказались более устойчивы к исследуемому стрессовому фактору.

Ключевые слова: марганеч, стресс, ячмень, всхожесть, длина корня, устойчивость.

\section{Influence of manganese on germination and linear growth of root system of barley of different varieties}

Simonova O. A., candidate agricultural sciences, scientific worker, Federal Agricultural Research Center of North-East named N.V. Rudnitsky, Kirov, Russia, simolga07@gmail.com; SimonovM.V., candidate of technical sciences, associate professor, Vyatka State University, Kirov, Russia; TovstikE. V., candidate of biology, associate professor, Vyatka State University, Kirov, Russia

tovstik2006@inbox.ru

The article presents the results of a study of the effect of manganese(II) ions in concentrations of 30.0, 60.0 and $90.0 \mathrm{mg} / \mathrm{l}$ on barley plants. The plants were grown in water culture for 7 days. 6 barley varieties were evaluated, including 5 
from the collection of the laboratory of selection and primary seed production of Federal Agricultural Research Center of North-East. It was found that the studied doses of manganese did not have a significant effect on seed germination. At the same time, with an increase in the concentration of manganese in the medium for growing barley plants, there was a natural decrease in the length of the roots. Zoned barley varieties, in comparison with the standard variety Belgorod 100, were more resistant to the studied stress factor in terms of the root length parameter and the values of the root length index (IDC).

Key words: manganese, stress, barley, germination, root length, resistance.

До настоящего времени селекция продолжает быть одним из наиболее доступных и эффективных способов создания новых сортов [1] Создаваемые сорта, в силу все возрастающего антропогенного воздействия на окружающую среду, должны быть устойчивыми к неблагоприятным факторам и почвенным стрессам. На дерново-подзолистых почвах Волго-Вятского региона такими факторами, прежде всего, являются повышенная кислотность и высокое содержание алюминия в почве [2]. Наряду с природными факторами, значительное влияние на развитие сельскохозяйственных культур оказывает загрязнение почвы тяжелыми металлами, особенно в условиях повышенной кислотности [3].

Одной из стратегически важных сельскохозяйственных культур является ячмень. Он наиболее чувствителен к почвенным стрессам, что обусловлено слаборазвитой корневой системой данного растения и низкой способностью к хелатообразованию [4]. Существует несколько параметров оценки устойчивости сельскохозяйственных культур к абиотическим факторам. Известно, что корневые системы играют значительную роль в успешном развитии растения и могут служить экспрессной информацией об их реакции на действие стрессоров [5-7]. Еще одним важным показателем металлоустойчивости растений может рассматриваться их всхожесть.

Объекты и методы. Объектами исследования служили растения ячменя сортов: 346-09; 12-29-11; Фермер 198-12; Форвард; Бионик из рабочей коллекции лаборатории селекции и первичного семеноводства ячменя ФГБНУ ФАНЦ Северо-Востока, а также Белгородский 100.

Семена ячменя выращивали в водной культуре: на дистиллированной воде (контроль) в течение семи суток. В качестве стрессового воздействия использовали ионы марганца (II) в концентрациях: 30,0; 60,0; и 90,0 мг/л действующего вещества (д. в.) для марганца. Элемент в среду вносили в виде соли: $\mathrm{MnSO}_{4} \times \mathrm{H}_{2} \mathrm{O}$.

Оценку устойчивости растений ячменя проводили по всхожести, длине корней и по соотношению длины корней в опыте и контроле (ИДК индекс длины корней).

Результаты и обсуждение. В результате проведенного опыта было 
выявлено, что марганец не оказал значительного влияния на прорастание семян ячменя (таблица). У двух сортов Белгородский 100 и 346-09 достоверного отличия всхожести семян в вариантах опыта по сравнению с контролем не было выявлено. По литературным данным, процесс прорастания семян является довольно устойчивым к действию тяжелых металлов $[8,9]$. Однако, у сортов Фермер 198-12, 29-11 и Бионик наблюдалось изменение всхожести семян при внесении в среду для выращивания растений максимальной дозы марганца (90 мг/л). При этом у сорта Фермер 198-12 было зафиксировано снижение данного параметра по отношению к контролю (86,20 \%), а у 29-11 и Бионик, напротив, повышение (112,50 и 106,43 \% соответственно). Несмотря на то, что при высоких концентрациях марганец может оказывать токсическое действие на развитие живых организмов, в тоже время он является биогенным элементом.

Таблица - Параметры устойчивости сортов ячменя к повышенным концентрациям марганца

\begin{tabular}{|c|c|c|c|c|c|}
\hline \multirow[b]{2}{*}{ Сорт } & \multirow{2}{*}{$\begin{array}{c}\text { Доза } \\
\text { марганца, } \\
\text { мг/л }\end{array}$} & \multicolumn{2}{|c|}{ Всхожесть } & \multicolumn{2}{|c|}{ Длина корня } \\
\hline & & Значения, \% & \% к контролю & Значения, см & иДК \\
\hline \multirow{4}{*}{ Белгородский 100} & 0 & $88,9 \pm 5,6$ & & $15,7 \pm 0,4$ & \\
\hline & 30 & $86,9 \pm 1,0$ & 97,75 & $13,2 \pm 0,3^{*}$ & 84,08 \\
\hline & 60 & $93,9 \pm 3,0$ & 105,62 & $12,2 \pm 0,1^{*}$ & 77,71 \\
\hline & 90 & $93,9 \pm 0$ & 105,62 & $11,5 \pm 0,3^{*}$ & 73,25 \\
\hline \multirow{4}{*}{$346-09$} & 0 & $87,9 \pm 3,5$ & & $17,0 \pm 0,1$ & \\
\hline & 30 & $88,9 \pm 5,6$ & 101,14 & $16,7 \pm 0,6$ & 98,24 \\
\hline & 60 & $83,8 \pm 4,0$ & 95,34 & $15,7 \pm 0,3^{*}$ & 92,35 \\
\hline & 90 & $85,9 \pm 7,1$ & 97,72 & $14,6 \pm 0,5^{*}$ & 85,88 \\
\hline \multirow{4}{*}{ Форвард } & 0 & $81,8 \pm 6,3$ & & $16,1 \pm 0,5$ & \\
\hline & 30 & $74,7 \pm 3,6$ & 91,32 & $16,5 \pm 0,2$ & 102,48 \\
\hline & 60 & $70,7 \pm 4,4^{*}$ & 86,43 & $15,4 \pm 0,3^{*}$ & 95,65 \\
\hline & 90 & $83,8 \pm 4,4$ & 102,44 & $13,1 \pm 1,1^{*}$ & 81,37 \\
\hline \multirow{4}{*}{ Фермер 198-12 } & 0 & $94,9 \pm 2,7$ & & $15,8 \pm 0,5$ & \\
\hline & 30 & $85,9 \pm 2,7^{*}$ & 90,52 & $17,4 \pm 0,1^{*}$ & 110,13 \\
\hline & 60 & $92,9 \pm 2,0$ & 97,89 & $14,5 \pm 0,7^{*}$ & 91,77 \\
\hline & 90 & $81,8 \pm 6,3^{*}$ & 86,20 & $12,8 \pm 0,6^{*}$ & 81,01 \\
\hline \multirow{4}{*}{$29-11$} & 0 & $80,8 \pm 7,9$ & & $14,4 \pm 0,3$ & \\
\hline & 30 & $94,9 \pm 1,0^{*}$ & 117,45 & $14,2 \pm 0,2$ & 98,61 \\
\hline & 60 & $87,9 \pm 3,5$ & 108,79 & $13,4 \pm 0,1^{*}$ & 93,06 \\
\hline & 90 & $90,9 \pm 1,7^{*}$ & 112,50 & $12,1 \pm 0,3^{*}$ & 84,03 \\
\hline \multirow{4}{*}{ Бионик } & 0 & $77,8 \pm 3,6$ & & $15,4 \pm 0,3$ & \\
\hline & 30 & $70,7 \pm 5,3$ & 90,87 & $14,9 \pm 0,4$ & 96,75 \\
\hline & 60 & $79,8 \pm 4,0$ & 102,57 & $14,2 \pm 0,3^{*}$ & 92,21 \\
\hline & 90 & $82,8 \pm 1,0^{*}$ & 106,43 & $13,4 \pm 0,4^{*}$ & 87,01 \\
\hline
\end{tabular}

Примечание: * - значения в опыте достоверно отличаются от контроля. 
В отличие от параметра всхожесть семян, оценкалинейного роста растений по развитию корневой системы позволила установить токсический эффект всех исследуемых доз марганца в варианте опыта с сортом Белгородский 100 (таблица). В этом случае отмечали закономерное уменьшение длины корней с увеличением концентрации исследуемого элемента в среде для выращивания растений. У остальных исследуемых в опыте сортов ячменя минимальная концентрация ионов марганца (II) не оказала достоверного влияния на линейный рост корней. Исключение составил сорт Фермер 198-12, для которого был установлен стимулирующий эффект (ИДК составил $110,13 \%$ ) данной дозы марганца (таблица).

По уровню устойчивости к повышенным концентрациям марганца все исследуемые сорта, согласно работе Navacode с соавт. [10], можно отнести к группе устойчивые (ИДК выше $65 \%$ ). Тем не менее, сорт Белгородский сорт имел более низкие значения ИДК (от 73,25 до 84,08) по сравнению с районированными сортами.

Таким образом, оценка устойчивости сортов ячменя позволила установить, что ионы марганца(II) в дозах 30,0; 60,0; 90,0 мг/л не оказывают выраженного действия на всхожесть семян и напротив, ингибируют линейный рост корневой системы проростков. Однако, несмотря на то, что в результате воздействия исследуемого стрессового фактора длина корней ячменя снизилась, но, по расчетным значениям ИДК, исследуемые сорта отнесены к группе устойчивых. Исключение составил сорт Белгородский 100, который и по длине корней и по ИДК, оказался менее устойчивым, по сравнению с районированными сортами ячменя.

\section{Список литературы}

1. Родина Н.А. Селекция ячменя на Северо-Востоке Нечерноземья / Н.А. Родина. - Киров: Зональный НИИСХ Северо-Востока, 2006. - 488 с.

2. Шихова Л.Н. Сезонная динамика кислотности естественной и мелиорированной дерново-подзолистой почвы / Л.Н. Шихова, Е.М. Лисицын // Плодородие. - 2014. - № 6 (81). - С. 40-41.

3. Небольсин А.Н. Известкование почв (результаты 50-летних полевых опытов). / А.Н. Небольсин, 3.П. Небольсина. - СПб.: ГНУ ЛНИИСХ Россельхозакадемии, 2010. $-254 \mathrm{c}$.

4. Щуплецова О.Н. Генетические источники селекции ячменя (Hordeum vulgare) в Волго-Вятском регионе / О.Н. Щуплецова, И.Н. Щенникова // Труды по прикладной ботанике, селекции и генетике. - 2019. - № 180 (1). - С. 82-88. DOI: 10.30901/2227-8834-2019-1-82-88.

5. Palta J.A. Crop root system behaviour and yield preface / J.A. Palta, J.C. Yang // Field Crops Res. - 2014. - Vol. 165. - P. 1-4. DOI: 10.1016/j.fcr.2014.06.024.

6. Raza A. Wheat root selections for sustainable production / A. Raza, M. Imtiaz, W. Mohammad // Sustainable Agriculture Reviews. - 2015. - Vol. 18. - P. 295-315. DOI: 10.1007/978-3-319-21629-4_10.

7. Лисицын Е.М. Показатели развития корневых систем в эдафической селекции 
ячменя / Е.М. Лисицын // Зернобобовые и крупяные культуры. - 2018. - № 2 (26). C. 66-71. DOI: 10.24411/2309-348X-2018-10019.

8. Shah K. Cadmium elevates level of protein, amino acids and alters activity of proteolytic enzymes in germinating rice seeds / K. Shah, R.S. Dubey // Acta Physiol. Plant. 1998. - V. 20, N. 2. - P. 189-196.

9. Холодова В. П. Адаптация к высоким концентрациям солей меди и цинка растений хрустальной травки и возможность их использования в целях фиторемедиации / В.П. Холодова, К.С. Волков, В.В. Кузнецов // Физиология растений. - 2005. - Т. 52, № 6. - C. 848-858.

10. Navacode S. A genetic analysis of aluminium tolerance in cereals / S. Navacode, A. Weidner, R. K. Varshney, U. Lohwasser, U. Scholz, M.S. Roder, A. Borner // Agric. Conspec. Sci. - 2010. - V. 75. - No. 4. - P. 191-196.

DOI 10.18699/GPB2020-110

\section{Урожайность сортов овса в контрастных гидротермических условиях Приобской лесостепи}

Сотник А.Я., к.с.-х.н., в.н.с., Костикова И.В., н.с.

Сибирский научно-исследовательский институт растениеводства и селекичии - филиал Института цฺитологии и генетики СО РАН, Новосибирская область, пос. Краснообск.

*e-mail:sibniirs@bk.ru

Исследования проводили в СибНИИРС - филиале ИЦиГ СО РАН в 2006-2019 гг. Материалом исследований явились 3 сорта овса селекиии СибНИИРС: Новосибирский 5, Новосибирский 88, Ровесник из питомника сибирского генофонда. Цель исследования - оценить сорта овса по способности формировать урожай в контрастных гидротермических условиях Приобской лесостепи Новосибирской области. Показано, что при распределении условий года на группы недостаточно использование только показателя ГТК за период развития растений. Отмечена сортовая специфичность по реализачии потенциала урожайности в разных гидротермических условиях. Сорт Новосибирский 88 относится к интенсивному типу, а сорт Новосибирский 5 - к экстенсивному типу.

Ключевые слова: овес, сорт, гидротермический коэффициент, урожайность.

\section{Yield varieties yield under contrast hydrothermal conditions of the forest steppe of the $\mathrm{Ob}$ region}

Sotnik A.YA. Candidate of Agricultural Sciences, Leading Researcher Kostikova I.V., Researcher

Siberian Research Institute of Plant Production and selection - branch of the Institute of Cytology and Genetics of the SB RAS, Novosibirsk Region, Krasnoobsk. 